\title{
RELIGION IN THE POST-LIBERAL TIME
}

\author{
Solveiga Krumina-Konkova \\ Institute of Philosophy and Sociology, University of Latvia \\ e-mail:konkova@latnet.lv
}

\begin{abstract}
The paper is devoted to the analysis of the transformation of religiosity in the post-liberal time and shows such cases of change in the religious life of Latvia. Post-liberalism means the intellectual tendency arisen during the second part of the $20^{\text {th }}$ century. It was first analysed in George Lindbeck's work "The Nature of the Doctrine: Religion and Theology in a Postliberal Age". One of the specific features of post-liberalism is "return to traditions" while adopting this tradition to the present cultural situation and offering new explanation concerning human nature, personal experience in the world and within the particular cultural milieu. The increase of the application of tendencies of post-liberalism within the religious institutions and beyond nowadays determines also the growing interest in the mysticism and mystical experience. The paper will address some Latvian cases, which, in the author`s opinion, are characteristic of post-liberal religiosity.
\end{abstract}

Keywords: Christian meditation, mystical experience, post-liberalism, radical traditionalism, return to traditions

First of all, let us briefly describe what the phenomenon of post-liberalism in general is. The post-liberalism means the intellectual tendency arisen during the second part of the $20^{\text {th }}$ century. American Lutheran theologian George Lindbeck (1923-2018) first analysed it in his work "The Nature of the Doctrine: 
Religion and Theology in a Postliberal Age" (Lindbeck 1984). Explaining the feeling which was somewhat intensive among Europeans already in that time, Lindbeck emphasised that Christian doctrines should not be understood as universalistic propositions or as interpretations of a universal religious experience. Following the Wittgensteinian concept of the language game, they are more like the rules of grammar that govern the way we use language to describe the world. In theology, the turning point to the post-liberalism means a cultural-linguistic approach to religion and the interpretative regulation of various Christian doctrines or the appearance of so-called rule theories (See, for example, Murphy 1993, Tanner 1997). Lindbeck equates Christian doctrine with 'subjective grammar', but the preaching of the gospel in the Christian Church - with a regulator and a continuous narrative. It is like a script, a script that must be implemented and can also be used as a resource for self-criticism of Christianity and the criticism of existing Christian culture.

However, it should be noted, that there is still debate on the chronological framework of post-liberalism and whether it is a single direction or maybe we have to talk about some even parallel-emerging kinds of post-liberalism with significant differences. When talking about the chronological framework, for example, Karl Barth who actively wrote in the 1950s-1960s, is often called as a post-liberal theologian. For example, an opinion exists that some characteristics of postmodernism appear in the Barth's approach that the infallibility of theology is based on the Bible. However, it might be more accurate to say that Barth is on the border between liberalism and post-liberalism. In his liberalism (as in the liberalism of the 1960s and 1970s, in general), specific signs of new post-liberalism appear, just as post-liberalism still has quite a lot of elements of liberalism.

Lindbeck has also named the main feature of post-liberalism: 'the return to tradition' while applying this tradition to the present cultural situation and offering a new answer to such well-known questions as What does God mean to the modern man? What is human nature or our being in the world and within the particular cultural milieu? In other words, the rationality of theology must be rooted in the language of living faith which, in its turn, is based on the particular Christian community and on the culture that this community creates. At the same time, the normative nature of the Christian narrative determines the way in which this language of living faith is created. Post-liberal theology could be characterised by a return to the patterns of reading and interpreting 
of gospels developed by the Fathers of early and medieval Church, that is, by combining the historically-grammatical reading and the spiritually-allegorical sensation in the coherent explanation of the Scriptures. Such an approach has led to post-liberalism being also called "radical traditionalism". Radicalism in this sense refers to the new methods used.

A typical example of this returning is the commentary on Biblical texts published by Brazos Press. So, on the one hand, there is the Bible's text as it is given to us, with its narrative. On the other hand, there are commentaries which take into account the relationship of this text with the particular Christian Church reading this text, with the identity of this church and the understanding of God which it worships. The same is true of critical studies of classical theological texts, such as of Saint Augustine or Saint Thomas of Aquinas, which respect the contemporary cultural discourse and the concepts used in it and therefore constitute an entirely new reading of one or the other text.

The increase of the application of tendencies of post-liberalism within the religious institutions and beyond nowadays determines also the growing interest in the mysticism and mystical experience. The importance of different kinds of mysticism and mystical theology can also be called a turning point toward the post-liberalism. The extensive encyclopaedia "Miracles. An Encyclopedia of People, Places, and Supernatural Events from Antiquity to the Present", published by ABC CLIO in 2016, also evidence an increasing interest in mysticism that cut across denominational lines. Further, one case about the development of mystical practices from Latvia will be mentioned.

Latvian Lutheran pastor Juris Rubenis for several years was one of the most known teachers of Christian meditation in Europe. In several books, he has tried to combine the ideas and practices of different mystical teachings, such as of Spanish Catholic mysticism and Zen Buddhism. At the beginning of the book "Introduction to Christian Meditation" he writes:

More and more contemporary people are searching not for words and thoughts, but for the direct mental experience. This thirst is multiplied, and the indicator is a desperate quest and a wide interest in various spiritual offerings. Of course, it is significant for everyone to find his way, but looking for it, it is important to know that a serious path of direct spiritual experience has always been available in Christian mystical theology, meditation and contemplation (Rubenis 2010: 10). 
The book of Rubenis is also a comprehensive insight into the teachings of three contemporary Christian mystics - Hugo Enomiya-Lassalle (1898-1990), Bede Griffiths (1906-1993) and John Main (1926-1982). According to Rubenis, these three mystics are united by the fact that they have made meditation accessible to everyone, showing that "the practice of poverty of spirit can be combined with the life of any modern person" (Rubenis 2010: 41).

One should note yet another common feature of these mystics: they practised and promoted meditation techniques of Eastern religions in the Christian context, creating a new meditation practice. (More about it: Krumina-Konkova 2016: 30-31.) However, as Rubenis writes, this is not in any way a talk about the creation of a syncretic new religion: the encounter with the East "encouraged them to look at Christianity differently and bring up the tradition of meditation that had been neglected unsuccessfully. Meeting with other traditions made them better, deeper, more faithful Christians" (Rubenis 2016: 42).

In 2009, Rubenis founded a meditation centre "Elijah House". In the same year "Elijah House" was named a member of The World Community for Christian Meditation. In 2011, Rubenis graduated from Lassalle Kontemplationsschule Via integralis in Zürich. After a year, he left his service as a pastor in Riga and entirely occupied himself with the leadership of his centre. True, in recent years there has been a conflict between Rubenis and his opponents in the Evangelical Lutheran Church of Latvia. Rubenis was blamed for the practising of meditation unacceptable for Lutheranism and for propaganda and recognition of homosexuality. As evidence, his book "She and He" (Rubenis 2016) about love, relationships and sex was cited. The conflict was so high that in February 2018 Rubenis left the post of the pastor. Commenting on this step, he emphasised that

this is a carefully considered and well thought out decision that results from long-standing external and internal processes in the Church and in me.

I will abstain from broader comments. Nothing has changed in my value system. I still consider it the most important task of my life to remain on the path to spiritual growth by learning to be a genuine, loving, braver person and to help find and follow this path for other people. I will continue to serve as a contemplative teacher at Elijah House and Institute for Integral Education (Jauns.lv. 2018). 
Despite the tensions among the Lutheran clergy, Rubenis' teaching of Christian meditation is widespread among Lutheran and other Christian laypersons, as well as in the Latvian society as a whole. At the beginning of 2017, the Silence and Meditation Room was also created at the National Library of Latvia. The authors of the idea of this place belong to the association under the name Symboli un Riti (Symbols and Rituals). They emphasise that

One might think that the room of silence and meditation is something exclusive, no, it is an acute necessity of today's life. We each need our dose of inner and spiritual calm. [--] Meditation is the path to this inner silence, self-awareness (Zilberts 2017).

The association's practice of meditation is related to the tradition of Via integralis, led by Rubenis. Nevertheless, the room of silence and meditation is also open to other schools of meditation.

As we see, the turn to post-liberalism appears in new forms of spirituality, the specificity of which is influenced by various liberal, neo-liberal and other political, economic and world-view contexts within the actual cultural situation. The case of the Baltic countries in this connection could be fascinating for extensive in-depth studies because here the post-liberal spiritual tendencies exist alongside expressly liberal and also excessively totalitarian strains of thought.

Another of the most visible examples of a post-liberal tendency in Protestantism is a communal transformation of liberal Protestantism in the way that it might begin to be more identifiable as a form of Catholic Christianity. Latvian Evangelical Lutheran Church is directly such a case. It should be remembered that Lindbeck also actively participated in the ecumenical dialogue with the Roman Catholic Church and, was a 'delegate observer' to the Second Vatican Council. The third example is the growing focus on Orthodoxy. During the last years, sociological surveys in Latvia show that Orthodoxy is one of the few Christian denominations, which has the fast-upward dynamics. Perhaps, a similar example could also be the conversion to fundamentalist groups of Islam of people with a Christian background. For example, among Latvians, former Christians, there are also ISIS adherents. The number of women wearing the niqab is also rising.

The Evangelical Lutheran Church of Latvia became closer to the Roman Catholic Church shortly after the archbishop Jānis Vanags took office in 1993. 
From now on, Vanags manifests himself as a conservative theologian, and the Latvian Evangelical Lutheran Church is considered as one of the most conservative Lutheran Churches in the world. One of Vanag's first innovations was the prohibition of women's ordination. This ban is also one of the reasons why the unity of the Lutheran Church in Latvia and the Latvian Evangelical Lutheran Church abroad does not take place. In 1999, nine independent Lutheran congregations united in one church, which was named the Confessional Lutheran Church. One of the reasons for the establishment of this church was also the rapprochement of the Latvian Evangelical Lutheran Church with the Latvian Roman Catholic Church.

Already in 2009, a group of the most conservative Lutherans made a suggestion, atypical for Lutheranism, - the creation of monk order and monasteries. In 2016, the highest decision-making organ of the Latvian Evangelical Lutheran Church, the Synod, took the appropriate decision, and now the first women's monastery is being built in Courland, and the Archbishop's blessing has also been received for the creation of a male monastery.

The building and the interior of the church of The Convent of the Holy Trinity of the women's monastery are designed accordingly to the Eastern or Byzantine tradition, because, as emphasised by the spiritual father Jānis Bitāns, it less appeals to the mind, more to heart, senses and feelings. However, as Bitāns said, "the Byzantine tradition would also be updated by a Latvian feature - the architect promised it!" (irLiepāja 2016).

It should be noted that the return to tradition is not always unmistakably clear, indisputable and sometimes should be considered with great caution. For example, in Spain, Alejandro García Sanjuán, a researcher at the University of Huelva, has published the article "The Persistence of National Catholic Discourse on Medieval Iberia in Current Spanish Historiography” (Sanjuán 2016: 132-153). In this article, he addresses the problem faced by the researchers of the Middle Ages. After the re-establishment of the Spanish Royal House in 1978, the so-called national patriotic historiography completely revises the history of Al-Andalus. Thus, just in 2016 Rafael Sánchez Saus published the book "AlAndalus and the Cross. The Muslim Invasion of Hispania” (Saus 2016) where the history of Al-Andalus, as it was described by Spanish medieval scholars from the $19^{\text {th }}$ and $20^{\text {th }}$ centuries, was ultimately denied. It has turned into a history of violence, leaving no room for cultural developments or religious tolerance, who ruled in the caliphate. The main singularity of the before-mentioned book 
of Saus lies in the fact that, despite its confessional perspective, it does not come from the clerical sphere, but from the academic world of the university. Sanjuán emphasises that such approach to the medieval Iberian past "may be summarised in two major features: the historical illegitimacy of al-Andalus from its origins, expressed through the notion of the Arab and Islamic "invasion" of Iberia, and the consequent legitimacy and glorification of the Christian conquest (so-called Reconquista), ending with the siege of Granada by the Catholic Kings in 1492" (Sanjuán 2016: 132). Sanjuán concluded that the national-Catholic historiography of the $21^{\text {st }}$ century, advocated in works such as "Al-Andalus and the Cross", is far from that what European integration requires today - "to give its place to communities like the Muslim in the history and the present of Europe" (Sanjuán 2016: 152). Therefore, the rewriting of history is the case when the return to tradition is to be seen more than just a return to Christianity, even if we are talking about Europe.

Some years ago Douglas John Hall, Canada's most celebrated living theologian, Emeritus Professor of Christian Theology at McGill University, wrote: "It is inevitable, I think, that the most serious Christians and Christian groupings will experiment with all kinds of new arrangements and alliances. Some of these will prove unhelpful and wrong, and some will be or become relevant will prove a way into the future" (Hall 2013: 34). The same we can say about the Latvian cases. However, no matter how religious life in Latvia will emerge in the future, one benefit is already undeniable: the current experiments are significant to preserve the sense of wonder and awareness of the mysterious boundary conditions of human experience and to renew the community of the people who need religious beliefs.

\section{References}

Hall, Douglas John 2013. What Christianity Is Not: An Exercise in Negative Theology. Eugene: Cascade Books.

Jauns.lv 2018. Juris Rubenis aiziet no amata Latvijas luterānu baznīcā un Jauns.lv atklāj šis aiziešanas iemeslus [Juris Rubenis left his post at the Latvian Lutheran Church and Jauns.lv reveals the reasons for his leave]. Jauns.lv, February 14. Available at http://jauns.lv/raksts/zinas/269929-juris-rubenis-aiziet-no-macitaja-amatalatvijas-luteranu-baznica-un-jaunslv-atklaj-sada-sola-iemeslus, last accessed on 03.04.2018. 
Krumina-Konkova, Solveiga 2016. "Mūžīgās mīlestības mūžīgi bērni”. Mistiskās teologijas piemēri Latvijā ["Eternal Children of Eternal Love”. Examples of Mystical Theology in Latvia]. Vērtības: Latvija un Eiropa. 2. sējums [Values: Latvia and Europe. Volume 2]. Riga: Institute of Philosophy and Sociology, University of Latvia.

Lindbeck, George A. 1984. The Nature of the Doctrine: Religion and Theology in a Postliberal Age. Louisville, Kentucky: Westminster John Knox Press.

Murphy, Nancey C. 1993. Theology in the Age of Scientific Reasoning. Cornell Studies in the Philosophy of Religion. Cornell University Press.

Pujēna, Sarmīte 2016. Siekstātē top pirmais luterāņu klosteris Latvijā [The first Lutheran monastery in Latvia is forming in Siekstate]. irLiepāja, August 29. Available at https://www.irliepaja.lv/lv/raksti/liepajnieki/sieksate-top-pirmais-luteranuklosteris-latvija/, last accessed on 03.04.2018.

Rubenis, Juris 2010. Ievads kristīgajā meditācijā [Introduction to Christian Meditation]. Riga: Zvaigzne ABC.

Rubenis, Juris 2016. Viņa un Viņš. Mīlestība. Attiecības. Sekss [She and He. Love. Relationship. Sex]. Riga: Zvaigzne ABC.

Sanjuán, Alejandro García 2016. La persistencia del discurso nacionalcatólico sobre el Medievo peninsular en la historiografía española actual [The Persistence of the National Catholic Discourse on the Peninsular Middle Ages in Current Spanish Historiography]. Historiografías, 12 (July-December), pp. 132-153.

Saus, Rafael Sánchez 2016. Al-Andalus y la cruz. La invasión musulmana de Hispania [Al-Andalus and the Cross. The Muslim Invasion in Hispania]. Barcelona: Stella Maris.

Tanner, Kathryn 1997. Theories of Culture. A New Agenda for Theology. Fortress Press. Zilberts, Augusts 2017. Latvijas Nacionālajā Bibliotēkā izveidota klusuma un meditācijas istaba [A Room of Silence and Meditation Is Established in the Latvian National Library]. Available at https://nb.lv/lv/latvijas-nacionalaja-biblioteka-izveidotaklusuma-un-meditacijas-istaba, last accessed on 03.04.2018. 